\title{
ANALISIS KEMAMPUAN BERPIKIR KREATIF MAHASISWA PENDIDIKAN AKUNTANSI DALAM MEMBUAT INSTRUMEN TES HASIL BELAJAR SISWA MELALUI PEMBELAJARAN BERBASIS PROYEK
}

\author{
(Analysis Of Creative Thinking Skills In Accounting Education Students To Create \\ Learning Test Instruments Through Project-Based Learning)
}

\section{Purba Andy Wijaya*) Nurhuda**)}

E-mail : purbaandywijaya@edu.uir.ac.id

*) **) FKIP, Universitas Islam Riau, Pekanbaru

\begin{abstract}
This study aims to describe the creative thinking skills of accounting education students in making test instruments through project-based learning. This research is a descriptive study with data collection using documentation study techniques and tests conducted at the end of the learning program. The study was conducted on 81 accounting education students who were divided into 26 groups. The results of this study indicate the ability to think creatively in groups in either category, 16 groups (61.54\%) are able to make questions with various categories. based on tests given to individual students, it showed 28 students (34.57\%) the ability of students to think creatively in either category.
\end{abstract}

Key words: creative thinking skills, project-based learning.

\section{PENDAHULUAN}

Di Era globalisasi ini, peningkatan daya saing bangsa salah satunya dapat dilakukan dengan peningkatan kualitas sumber daya manusia (SDM). Softskill kemampuan penalaran dan kreativitas, harus dibangun bagi lulusan perguruan tinggi di Indonesia. Sejalan dengan hal ini, Santrock (2011) menjelaskan berpikir adalah memanipulasi atau mengelola dan mentransformasikan informasi dalam memori. Ini sering dilakukan untuk membentuk konsep, bernalar, dan berpikir secara kritis, membuat keputusan, berpikir kreatif, dan memecahkan masalah.

Selain itu, Siswono (2008) dalam Rahmawanti (2017) mengatakan bahwa manusia yang dibekali akal budi, dan karsa menciptakan perubahanperubahan terhadap pengetahuan yang ada dan mengimplementasikannya untuk memecahkan masalah masalah yang dihadapi. Untuk itu diperlukan kemampuan berpikir kreatif menghadapi dan mengatasinya.

Program studi Pendidikan Akuntansi FKIP UIR merupakan salah satu program studi yang dirancang untuk menciptakan guru Akuntansi. Dalam undang-undang tentang pendidikan tinggi nomor 12 tahun 2012, perguruan tinggi memiliki fungsi mengembangkan potensi mahasiswa agar menjadi manusia yang beriman dan bertakwa kepada Tuhan Yang Maha Esa dan berakhlak mulia, sehat, berilmu, cakap, kreatif, mandiri, terampil, kompeten, dan berbudaya untuk kepentingan bangsa. Dengan demikian, salah satu kompetensi yang harus dimiliki oleh mahasiswa calon guru Akuntansi, berdasarkan undang undang di atas adalah kemampuan berpikir 
keratif. Kemampuan ini dibutuhkan dalam melaksanakan tugastugasnya sebagai guru. Kretatifitas juga merupakan kemampuan yang dituntut oleh dunia kerja saat ini.

Fakta yang diperoleh berdasarkan observasi pada saat proses perkuliahan yaitu masih belum optimalnya kemampuan berpikir kreatif mahasiswa baik pada saat proses pembelajaran di kelas maupun penyelesaian tugas yang diberikan. Pada saat proses perkuliahan masih ada beberapa dosen yang masih belum mengoptimalkan kemampuan kreatif siswa, hal ini dapat dilihat dari metode pembelajaran yang sering digunakan yaitu presentasi dan diskusi, banyak mahasiswa yang masih cenderung pasif. Metode presentasi dan diskusi yang sering dilakukan oleh mahasiswa pada umumnya bersifat text book atau membaca makalah, dan belum bisa menghubungkan dan mengembangkan suatu topik permasalahan pada kasus-kasus yang ada di lapangan. Selain itu, dari tugastugas yang telah diberikan masih ada beberapa mahasiswa yang dalam proses pengerjaannya masih banyak yang meminta jawaban dari teman satu kelas.

Upaya mendorong kemampuan berpikir kreatif sebagai bekal hidup menghadapi tuntutan, perubahan, dan perkembangan zaman lazimnya melalui dunia pendidikan yang berkualitas (Siswono, 2008). Semua bidang pendidikan tanpa terkecuali pendidikan akuntansi mulai mengarahkan pada tujuan itu. Pendidikan tersebut mengarahkan dan mengantarkan peserta didik menjadi pembelajar yang kreatif dan berkualitas. Sejalan dengan ini, proses pembelajaran pada suatu perguruan tinggi diharapkan menumbuhkan jiwa yang kreatif dan inovatif.

Pembelajaran berbasis proyek (Project Based Learning) merupakan metode pembelajaran yang mengacu pada filosofi konstruktivisme yaitu pengetahuan merupakan hasil konstruksi kognitif melalui aktivitas siswa yang meliputi keterampilan ataupun sikap ilmiah sehingga siswa dapat mengonstruksi pengetahuannya sendiri dan bermakna melalui pengalaman nyata. Kerja proyek yang memuat tugas-tugas yang kompleks berdasarkan pertanyaan dan permasalahan (problem) yang sangat menantang dan menuntut siswa untuk merancang, memecahkan masalah, membuat keputusan, melakukan kegiatan investigasi serta memberikan kesepatan kepada siswa untuk bekerja secara mandiri (Okudan, 2004).

Menurut Rais (2010) Pembelajaran berbasis proyek dapat dipandang sebagai salah satu pendekatan penciptaan lingkungan belajar yang dapat mendorong siswa mengkonstruk pengetahuan dan keterampilan secara personal. Pembelajaran berbasis proyek akan memberikan kesempatan kepada siswa belajar secara mandiri sehingga mampu mengkonstruksi pengetahuan sendiri dan selanjutnya mampu menerapkan dalam penyelesain proyek dan mengaplikasikan dalam kehidupan sehari-hari.

Menurut Nurhadi dan Senduk (2004) pembelajaran berbasis proyek memiliki 4 ciri sebagai berikut : 1) adanya pengajuan masalah atau pertanyaan yang berorientasi pada situasi kehidupan nyata yang autentik dan memungkinkan adanya berbagai macam solusi, 2) berfokus pada keterkaitan antar disiplin ilmu 3) Penyelidikan autentik, mengharuskan siswa melakukan penyelidikan autentik untuk mencari penyelesaian nyata terhadap masalah nyata. 4) menghasilkan produk/karya nyata atau artefak, laporan, model dan peragaan 
yang menjelaskan atau mewakili bentuk masalah yang disajikan.

Berdasarkan paparan di atas, maka akan dilakukan penelitian dengan judul "Analisis Kemampuan Berpikir Kreatif Mahasiswa dalam Pembuatan Instrumen Tes Hasil Belajar Siswa Melalui Model Pembelajaran Project Based Learning”.

\section{METODE PENELITIAN}

Penelitian ini merupakan penelitian dengan jenis deskriptif dengan pendekatan survei. Tujuan dari penelitian ini untuk mengetahui gambaran kemampuan berpikir kreatif mahasiswa dalam membuat instrument tes melalui metode pembelajaran berbasis proyek.

Subjek penelitian ini merupakan seluruh mahasiswa program studi Pendidikan Akuntansi semester 6 angkatan 2015 yang terdiri dari 4 kelas dengan jumlah mahasiswa secara keseluruhan sebanyak 81 mahasiswa.

Teknik pengumpulan data dalam penelitian ini menggunakan studi dokumentasi dan tes. Data hasil penelitian dari studi dokumentasi merupakan data yang diperoleh dari hasil tugas proyek mahasiswa dalam membuat instrument tes beserta analisis butir soal yang dikerjakan secara berkelompok, sedangkan data hasil penelitian dari tes digunakan untuk menganalisis kemampuan mahasiswa secara individu.

Data yang diperoleh dari hasil studi dokumentasi dianalis dengan menggunakan daftar checklist kategori soal berdasarkan tingkatan kognitif $\mathrm{C} 1$ (remember), C2 (understand) serta C3 (apply), C4 (analyze), C5 (evaluate) dan C6 (create), sedangkan data hasil tes dianalisis berdasarkan jawaban mahasiswa dalam mengembangkan soal.
Tabel 1. Subjek Penelitian

\begin{tabular}{|c|c|c|c|c|c|}
\hline \multirow{2}{*}{ Keterangan } & \multicolumn{4}{|c|}{ Kelas } & \multirow{2}{*}{ Total } \\
\cline { 2 - 5 } & A & B & C & D & \\
\hline $\begin{array}{c}\text { Jumlah } \\
\text { Mahasiswa }\end{array}$ & 22 & 20 & 17 & 22 & $\begin{array}{c}81 \\
\text { Mahasiswa }\end{array}$ \\
\hline $\begin{array}{c}\text { Jumlah } \\
\text { Kelompok }\end{array}$ & 7 & 7 & 6 & 6 & $\begin{array}{c}26 \\
\text { Kelompok }\end{array}$ \\
\hline
\end{tabular}

Berdasarkan tabel di atas dalam pelaksanaan pembelajaran proyek mahasiswa dibagi kedalam kelompok kecil.

\section{HASIL}

Hasil Studi Dokumentasi Tugas Proyek Mahasiswa

Tabel 2. Kategori soal yang dihasilkan oleh kelompok belajar

\begin{tabular}{|c|c|c|c|c|c|}
\hline \multirow{2}{*}{$\begin{array}{c}\text { Kategori } \\
\text { soal }\end{array}$} & \multicolumn{4}{|c|}{ Kelas } & \multirow{2}{*}{ Total } \\
\hline & A & B & $\mathrm{C}$ & D & \\
\hline $\mathrm{C} 1$ & 80 & 45 & 67 & 71 & 263 soal \\
\hline $\mathrm{C} 2$ & 75 & 56 & 69 & 51 & 251 soal \\
\hline $\mathrm{C} 3$ & 16 & 73 & 29 & 41 & 159 soal \\
\hline $\mathrm{C} 4, \mathrm{C} 5, \mathrm{C} 6$ & 40 & 36 & 15 & 17 & 108 soal \\
\hline
\end{tabular}

Berdasarkan tabel di atas, dalam membuat soal masing-masing kelas secara keseluruhan dapat membuat soal berdasarkan kategori. Jumlah soal dengan kategori C1 sebanyak 263 soal, kategori C2 sebanyak 251 soal, C3 sebanyak 159 soal, kategori C4, C5, dan C6 sebanyak 108 soal. Data tersebut menunjukkan bahwa kreatifitas mahasiswa Pendidikan Akuntansi dalam membuat soal lebih banyak tersebar di kategori C1, C2, dan C3 sebanyak 673 soal, sedangkan untuk kategori C4, C5, dan C6 sebanyak 108 soal. 


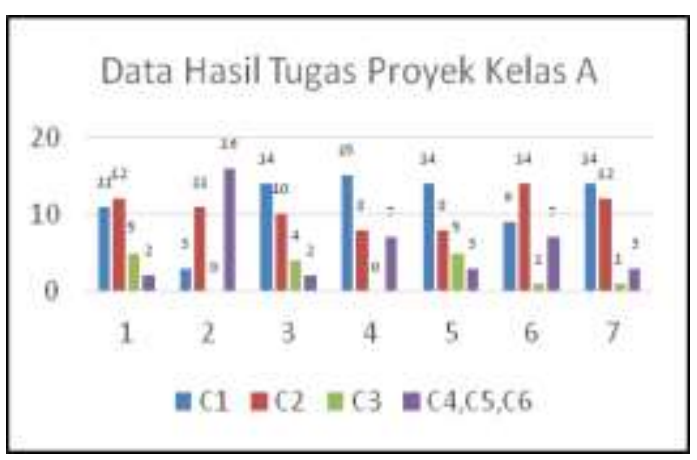

Gambar 1. Hasil Tugas Proyek Kelas A

Berdasarkan gambar 1 di atas, kelas A terbagi ke dalam 7 kelompok belajar, dari tugas proyek yang sudah dikumpulkan, 2 kelompok tidak mampu membuat soal dalam kategori C3 (aplikasi). Soal yang paling banyak dibuat oleh masing-masing kelompok di kelas A adalah soal dengan kategori $\mathrm{C} 1$ dengan rata-rata sebesar 11,43 soal, sedangkan soal dengan kategori C3 paling sedikit dibuat dengan rata-rata sebesar 2,29.

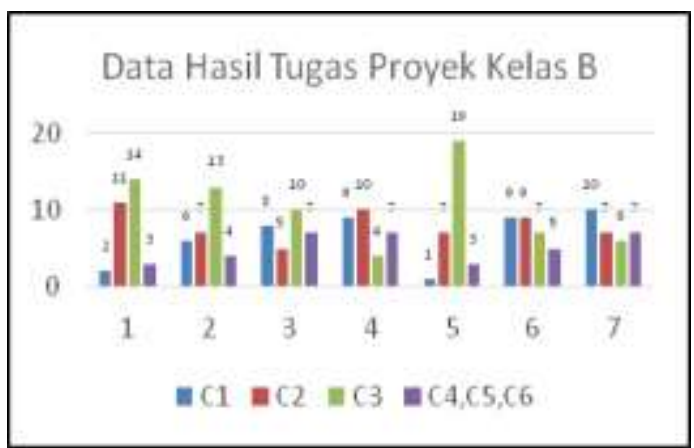

Gambar 2. Hasil Tugas Proyek Kelas B

Gambar 2 di atas menunjukkan kelas B terbagi ke dalam 7 kelompok belajar. Secara keseluruhan masing-masing kelompok di kelas B sudah memmpu membuat variasi soal ke seluruh kategori. Dari studi dokumentasi yang dikumpulkan, soal dengan kategori C3 memiliki jumlah terbanyak dengan ratarata 10,43 soal, sedangkan untuk kategori C4,C5,dan C6 memiliki jumlah paling sedikit dengan rata-rata 5,14 soal.

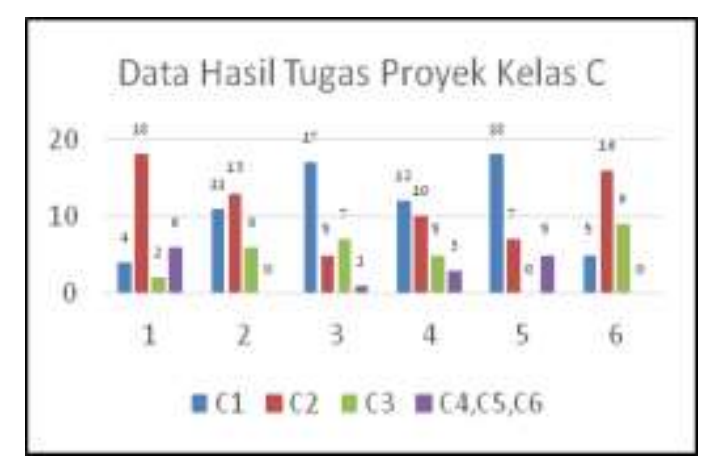

Gambar 3. Hasil Tugas Proyek Kelas C

Dalam melaksanakan tugas proyek, kelas C dibagi kedalam 6 kelompok belajar. Berdasarkan gambar 2 di atas, terdapat 3 kelompok yang tidak mampu membuat soal dalam kategori C4,C5, dan C6, sedangkan 1 kelompok tidak dapat membuat soal dengan kategori C3.

Kategori soal yang sudah dibuat oleh masing-masing kelompok di kelas $\mathrm{C}$ tertinggi pada kategori $\mathrm{C} 2$ dan $\mathrm{C} 1$ dengan rata-rata masing-masing kategori tersebut sebesar 11,50 (C1) dan 11,17 (C2). Jumlah soal paling sedikit yang dibuat oleh kelompok di kelas $\mathrm{C}$ adalah soal dengan kategori C4, C5, C6 dengan rata-rata sebesar 2,5 soal.

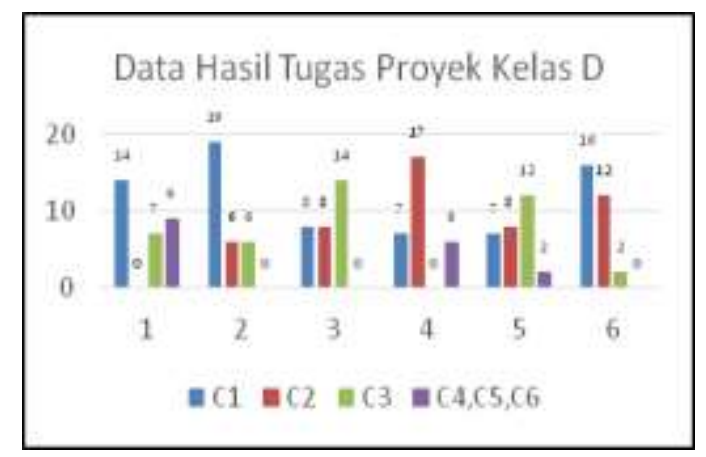

Gambar 4. Hasil Tugas Proyek Kelas D

Kelas D terbagi ke dalam 6 kelompok belajar. Hasil tugas proyek yang telah terkumpul, dapat dilihat bahwa hanya 1 kelompok (kelompok 5) yang dapat membuat soal dengan semua kategori $\mathrm{C} 1$ sampai dengan C6. Tiga kelompok $(2,3,6)$ tidak dapat membuat 
soal dengan kategori C4, C5,C6. Kelompok 1 tidak dapat membuat soal dengan kategori C2, sedangkan kelompok 4 tidak dapat membuat soal dengan kategori C3. Rata-rata tertinggi soal yang telah dibuat pada kelas D adalah soal dengan kategori $\mathrm{C} 1$ sebesar 11,83. Soal dengan kategori C4,C5,C6 memiliki jumlah terendah dengan ratarata sebesar 2,83.

Hasil Tes Akhir Kemampuan Berpikir Kreatif Mahasiswa

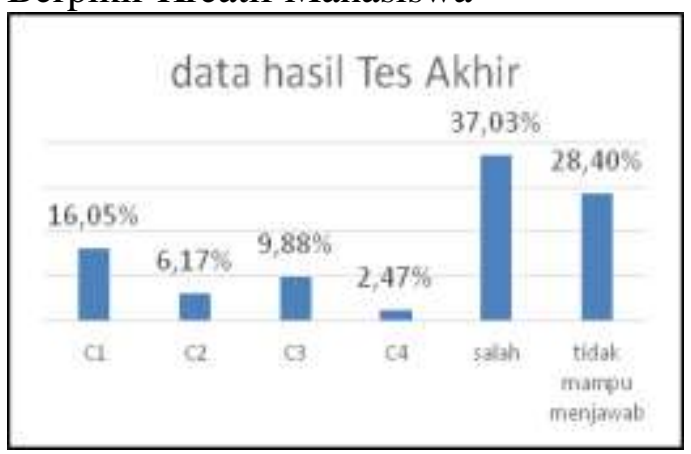

Gambar 5. Persentase kemampuan mahasiswa menjawab tes

Analisis kemampuan berpikir kreatif setiap mahasiswa dalam membuat soal dilakukan dengan menggunakan tes pada akhir pembelajaran. Tes yang digunakan dalam penelitian ini menggunakan jenis tes essay/uraian. Tes tersebut berisi tentang cuplikan dari RPP yang terdiri dari Kompetensi dasar, materi dan indikator. Mahasiswa dituntut untuk mengembangkan atau membuat soal tes berdasarkan data soal tersebut.

Hasil dari tes akhir ini dapat dilihat pada gambar 5. Dari keseluruhan jumlah mahasiswa (81 orang) dapat dilihat bahwa mahasiswa yang mampu mengembangkan soal pada kategori C1 sebanyak 13 orang $(16,05 \%), \mathrm{C} 2$ sebanyak 5 orang $(6,17 \%)$, C3 sebanyak 8 orang $(9,88 \%), \mathrm{C} 4$ sebanyak 2 orang $(2,47 \%)$, sedangkan mahasiswa yang mampu membuat soal tetapi tidak sesuai dengan ketentuan tes akhir sebanyak 30 orang $(37,03 \%)$. Gambar di atas juga menunjukkan mahasiswa tidak menjawab soal tes akhir sebanyak 23 orang $(28,40 \%)$.

\section{PEMBAHASAN}

Dalam menganalisis kemampuan berpikir kreatif mahasiswa dalam membuat intrumen tes dilakukan dengan menggunakan studi dokumentasi dan tes pada akhir proses pembelajaran. Data studi dokumentasi diperoleh melalui laporan akhir dari tugas proyek yang dilakukan oleh kelompok mahasiswa. Data yang bersumber dari tes dilakukan untuk mengetahui analisis atau gambaran kemampuan berpikir kreatif mahasiswa secara individu.

Berdasarkan analisis data yang telah dilakukan terhadap dua data tersebut, dapat diketahui terdapat perbedaan hasil. Data yang bersumber dari studi dokumentasi menunjukkan 16 kelompok dapat membuat soal dengan berbagai kategori soal dengan baik. Sementara 10 kelompok kurang baik dalam membuat soal. Hal tersebut dikarenakan 10 kelompok tidak mampu membuat soal pada salah satu kategori soal. Secara jelas dapat dilihat pada gambar 6 di bawah ini.

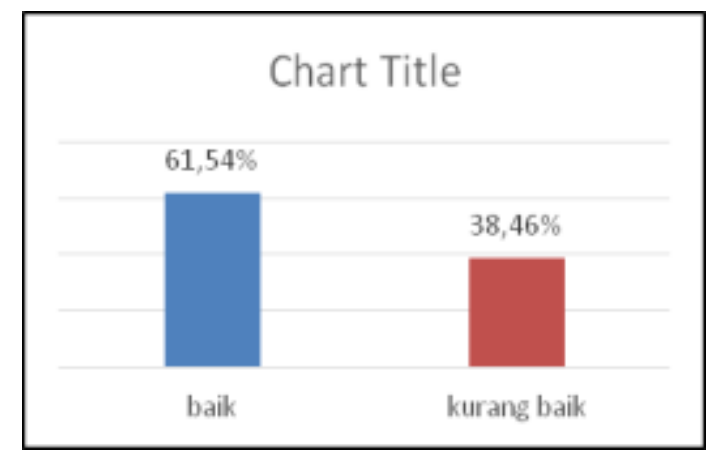

Gambar 6. Kemampuan kelompok dalam membuat soal

Hasil pengumpulan data melalui studi dokumentasi belum sepenuhnya menggambarkan kemampuan berpikir kreatif mahasiswa secara individu, 
maka dari itu pengumpulan data melalui tes sangat diperlukan.

Hasil dari tes akhir yang telah dilakukan untuk mengetahui kemampuan berpikir kreatif mahasiswa menunjukkan hasil yang berbeda dengan hasil data studi dokumentasi. Dari 81 orang mahasiswa Pendidikan Akuntansi, hanya 28 orang yang mampu membuat soal dengan baik dan benar, 30 orang mahasiswa membuat soal tidak sesuai dengan ketentuan, 23 orang mahasiswa tidak mampu menjawab tes atau membuat soal. Gambar 7 menunjukkan secara detail kemampuan berpikir kreatif mahasiswa dalam membuat soal tes.

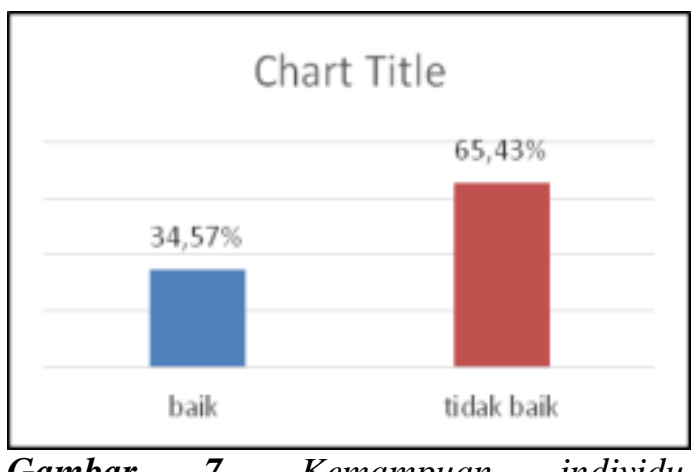

Gambar 7. Kemampuan individu mahasiswa dalam membuat soal

Perbedaan antara data hasil tes dengan studi dokumentasi tugas proyek menunjukkan bahwa kurang berperannya mahasiswa dalam keterlibatan pembuatan tugas proyek yang diberikan. Mahasiswa yang pasif dalam kegiatan kelompok akan mengalami kesulitan dalam menyelesaikan tes dalam membuat soal. Abidin (2013: 117) juga menjelaskan kelemahan dalam metode pembelajaran berbasis proyek diantaranya peserta didik yang memiliki kelemahan dalam percobaan dan pengumpulan informasi akan mengalami kesulitan, selanjutnya adanya kemungkinan peserta didik yang kurang aktif dalam kerja kelompok, artinya dalam kegiatan belajar dalam kelompok hanya didominasi oleh beberapa orang siswa.

Dalam membuat intrumen tes, selain dibutuhkan kreatifitas mahasiswa, penguasaan terhadap materi yang akan dimasukkan ke dalam instrumen tes serta penguasaan terhadap teknik evaluasi juga sangat berperan penting. Suryabrata (Purnomo, 2005) menjelaskan untuk dapat menyusun soal yang baik maka diperlukan kemampuan khusus dalam beberapa aspek diantaranya, 1) penguasaan akan materi yang diujikan, (2) kesadaran akan tata nilai yang mendasari pendidikan, 3) pemahaman akan karakteristik siswa, 4) kemampuan menuangkan gagasan dalam bahasa/kalimat, (5) penguasaan akan teknik penulisan soal, dan 6) kesadaran akan kekuatan dan kelemahan dalam menulis soal.

Dalam pelaksanaan pembelajaran berbasis proyek, perlu bagi dosen untuk memperhatikan karakteristik peserta didiknya, serta menekankan pada pembagian tugas individu dalam kelompok. Schunk, dkk. (2012) menjelaskan peserta didik termotivasi secara intrinsik mengerjakan tugastugas karena tugas tersebut menyenangkan, sedangkan yang termotivasi secara ektrinsik mengerjakan tugas karena dapat menyebabkan berbagai konsekuensi yang diinginkan, seperti mendapatkan hadiah, pujian, atau terhindar dari hukuman.

\section{IMPLIKASI}

Kemampuan berpikir kreatif mahasiswa dalam membuat instrument tes melalui pembelajaran berbasis proyek pada kategori baik secara kelompok sebesar $61,54 \% \quad(16$ kelompok), sedangkan secara individu sebesar $34,57 \%$ (28 orang). 


\section{REFERENSI}

Abidin, Yunus. 2014. Desain sistem pembelajaran dalam konteks kurikulum 2013.Bandung: PT Refika Aditama

David Firna Setiawan dan Aryan Eka Prastya Nugraha. 2017. Peningkatan Aktivitas Menggunakan Laboratorium Komputer Dan Hasil Belajar Siswa Smk Program Keahlian Akuntansi Melalui Penerapan Project Based Learning. Lampung: Jurnal Promosi Vol. 5 No. 1 (1-16) http://ojs.fkip.ummetro.ac.id/index. php/ekonomi/article/viewFile/841/6 51 diakses 14 Agustus 2017 pukul. 20.09.03 wib

Eddy Mufiannoor, M. Thamrin Hidayat, Soetjipto. 2016. Melatihkan Kemampuan Berpikir Kreatif Dan Pemahaman Konsep Dengan Pembelajaran Berbasis Inkuiri Terbimbing Pada Materi Interaksi Makhluk Hidup Dengan Lingkungan. Vol. 5, No. 2, Mei 2016. Surabaya: Pendidikan Sains Pascasarjana Universitas Negeri Surabaya https://journal.unesa.ac.id/index.ph p/jpps/article/viewFile/502/355 diakses 14 Agustus 2017 pukul. 20.04.03 wib

IB. Siwa, I W. Muderawan, I N.Tika. 2013. Pengaruh Pembelajaran Berbasis Proyek Dalam Pembelajaran Kimia Terhadap Keterampilan Proses Sains Ditinjau Dari Gaya Kognitif Siswa. Bali: eJournal Program Pascasarjana Universitas Pendidikan Ganesha Program Studi IPA (Volume 3 Tahun 2013)

Munandar. U. 2009. Pengembangan Kreativitas Anak Berbakat. Jakarta: PT Rineka Cipta

Nurhadi \& Senduk. 2004. Pembelajaran Kontekstual dan Penerapannya dalam KBK. Malang: Universitas Negeri Malang.

Okudan, Gul E. dan Sarah E, Rzasa, (2004). "A Project-Based Approach to Enterprenurial Leadership Education". Journal Technovation. Desember. Vol. 20. pp. 1-16

Pehkonen, Erkki. 1997. "The State-ofArt in Mathematical Creativity". ZDM Volum 29 (June 1997) Number 3. Electronic Edition ISSN 1615-679X.

http://www.fiz.karlsruhe.de/fiz/publ ications/zdm

Purnomo, Arif. 2007. Kemampuan Guru Dalam Merancang Tes Berbentuk Pilihan Ganda Pada Mata Pelajaran Ips Untuk Ujian Akhir Sekolah (UAS). Semarang: Lembaran Ilmu Kependidikan jilid 36 No. 1.

Rais, M. 2010. "Project Based Learning : Inovasi Pembelajaran Berorientasi Soft Skill". Makalah Disajikan Pada Seminar Nasional Pendidikan Teknologi dan Kejuruan Fakultas Tehnik Universitas Negeri Surabaya, Surabaya.

Rais. M. 2010. Model Project BasedLearning Sebagai Upaya Meningkatkan Prestasi Akademik Mahasiswa. Jurnal Pendidikan dan Pengajaran, Jilid 43. Nomor 3, Oktober 2010. Hlm. 246-252

Santrock, J. W. 2011. Psikologi Pendidikan. Jakarta: Kencana Prenada Media Group.

Schunk, D.H., Pintrich, P.R., dan Meece, J.L. 2012. Motivasi dalam pendidikan: Teori, penelitian, dan aplikasi. (Penerjemah: Ellys Tjo). Jakarta: PT. Indeks

Siswono, T. Y. 2008. Model Pembelajaran Matematika Berbasis Pengajuan dan Pemecahan Masalah Untuk Meningkatkan Kemampuan Berpikir Kreatif. Surabaya: Unesa University Press. 
Siswono, T.Y.E. 2006. Konstruksi Teoritik Tentang Tingkat Berpikir Kreatif Siswa Dalam Matematika. Jurnal Univbuana.

Sugiyono. 2011. Statistika untuk Penelitian. Bandung: Alfabeta

Sukardi. 2008. Evaluasi Pendidikan: Prinsip \& Operasional. Jakarta: Bumi Aksara.
Suryabrata, $\quad$ Sumadi. 1987. Pengembangan Tes Hasil Belajar. Jakarta : Rajawali.

Zainuddin, M. 2005. Praktikum. Jakarta: Pusat Antar Universitas Untuk Peningkatan dan Pengembangan Aktivitas Instruksional Universitas Terbuka. 